\title{
GMR
}

\section{Genetic analysis of drought tolerance with respect to fiber traits in upland cotton}

\author{
R.A. Nasimi, I.A. Khan, M.A. Iqbal and A.A. Khan \\ Department of Plant Breeding and Genetics, University of Agriculture, \\ Faisalabad, Pakistan \\ Corresponding author: R.A. Nasimi \\ E-mail: rizwannasimi1843@gmail.com
}

Genet. Mol. Res. 15 (4): gmr.15048626

Received March 21, 2016

Accepted July 6, 2016

Published October 5, 2016

DOI http://dx.doi.org/10.4238/gmr.15048626

Copyright $($ C 2016 The Authors. This is an open-access article distributed under the terms of the Creative Commons Attribution ShareAlike (CC BY-SA) 4.0 License.

\begin{abstract}
Cotton germplasm was analyzed to investigate its potential for developing water stress tolerance in varieties in the future. Four tolerant (NIAB-78, CIM-482, BH-121, and VH-142) and four susceptible (CIM-446, FH-1000, FH-900, and FH-901) lines were identified of 50 accessions based on their seedling root length. A complete set of diallel crosses among eight selected genotypes was subjected to genetic analysis for fiber property traits. Additive and non-additive genetic variance was involved in the inheritance of fiber strength, fineness, and length under normal and drought conditions. A large proportion of genetic variance was additive, which was further supported by moderately high narrow-sense heritability estimates for the characters. Graphic representation of variance versus covariance also depicted additive gene activity with partial dominance and the absence of non-allelic interactions in trait inheritance. The results of this study suggest that drought tolerance of cotton genotypes can be improved through crosses among tolerant
\end{abstract}

Genetics and Molecular Research 15 (4): gmr.15048626 
genotypes using conventional selection procedures in segregating generations.

Key words: Diallel analysis; Water stress; Additive genetic variance; Fiber traits; Non-additive genetic variance; Fiber fineness

\section{INTRODUCTION}

Gossypium hirsutum L. originated from perennial plants, and was adapted to semitropical and subtropical environments, such as those facing extremes of temperature and periodic drought (Kohel, 1974). Increases in temperature decrease the productivity of crop plants due to heat stress. In many areas, sowing cotton seeds results in the surface layer drying out due to the evaporation of moisture (Munro, 1987), and subsequent germination is severely affected. Severe drought slows the development of cotton plants that leads to very small boll size and the shedding of squares stress. It also causes many phenotypic changes such as stunted growth and reduced leaf area (Turner, 1986; Ball et al., 1994; Gerik et al., 1996), shoot growth, plant height, and yield (McMichael and Quisenberry, 1991). Plants adopt and develop mechanisms to cope with stressful conditions. A number of physiological and morphological traits are considered important parameters for drought tolerance in cotton, such as weight of the tap root, seedling vigor, number of lateral roots, speed of root system development, rootto-shoot ratio (Cook, 1985), greater tap root length (Pace et al., 1999), reduced transpiration (Quisenberry et al., 1982), conductance through stomata, rate of photosynthesis (Nepomuceno et al., 1998), relative leaf water content and discrimination of carbon isotopes (Leidi et al., 1999), and thermostability of cellular membranes (Sullivan, 1972). Plants have also been reported to develop drought tolerance in response to the production of high levels of antioxidants, polyphenols, polyenes, and carotenoids. Such plant characteristics have been used by breeders in preliminary studies aiming to breed drought-tolerant cotton varieties. Riaz et al. (2013) investigated five advanced lines of cotton at the seedling stage under three drought shock conditions. Based on positive correlations between shoot length, root length, root and shoot dry weight, it was recommended that these should be simultaneously selected as indices of drought tolerance. Rana et al. (2011) recommended the combined use of relative electrolyte leakage, chlorophyll stability, and differential sodium dodecyl sulfate polyacrylamide gel electrophoresis (SDS-PAGE) data obtained during stress tolerance screening. Such screening parameters are useful in programs aimed at developing drought-tolerant cotton varieties if variability is genetically controlled.

In the present study, a range of drought-tolerant phenotypes were examined at the seedling stage. Germplasm was screened on the basis of seedling traits, especially root length, because root length is a reliable and important indicator of drought tolerance (Basal et al., 2005). Identified tolerant and susceptible genotypes were subjected to further genetic analysis to assess the inheritance of fiber property traits. The information generated from these investigations may be helpful for developing programs aimed at improving cotton plants for drought tolerance.

\section{MATERIAL AND METHODS}

The study was conducted in the Department of Plant Breeding and Genetics, University

Genetics and Molecular Research 15 (4): gmr.15048626 
of Agriculture, Faisalabad, Pakistan, during the years 2010-2013. The experimental material was developed from 50 cotton accessions taken from the department's germplasm collection and was evaluated through screening. After screening, eight accessions (tolerant: NIAB-78, CIM-482, BH-121, and VH-142, and susceptible: FH-900, FH-1000, CIM-446, and FH-901) were selected on the basis of root length.

Selected accessions were grown in a glasshouse in pots of mud filled with fertile soil. Two seeds were sown in each pot. Following germination, only one seedling/plant was kept in a pot. All cultural practices were adopted and adhered to for proper plant development. At the flowering stage, the genotypes were crossed in order to develop a complete set of diallel crosses, including selfs. A complete record of the crosses was maintained. At maturity, the selfed and crossed bolls were picked and seed cotton was ginned to obtain seed.

The genotypic responses to normal and water stress treatments were assessed under field conditions in May 2013. All 64 entries were planted in a randomized complete block design with three replicates. The seeds were planted in rows $75 \mathrm{~cm}$ apart with plants spaced at $30 \mathrm{~cm}$ within the rows. A single row of each accession contained 10 plants. Under controlled conditions, plants were provided with normal water or $50 \%$ less water for subsequent drought analyses at maturity; five plants per accession for each treatment were tagged and seed cotton was picked. Following ginning, the lint was evaluated for fiber property traits.

\section{Fiber strength, length, and fineness}

The fiber strength, fineness, and length of each plant were measured with the help of a spin lab HVI-900. This provides a complete profile of raw fiber and measures the important characteristics of fiber according to international trading standards.

\section{Statistical analysis}

Data were analyzed for variance as suggested by Steel et al. (1997), revealing significant differences among the genotypes for all traits studied. Genetic analyses were performed using diallel analysis following the methods described by Hayman $(1954 a, b)$ and Jinks (1954), and exemplified by Mather and Jinks (1982).

\section{RESULTS}

Analysis of variance revealed highly significant variation at genotypic level for all the fiber traits under normal and water stress condition as shown in Table 1 and Table 2. Joint regression analysis and analysis of variance of $\mathrm{Wr}+\mathrm{Vr}$ (difference between the arrays) and $\mathrm{Wr}-\mathrm{Vr}$ (differences within the arrays) were applied to test the adequacy of the additivedominance model for the data, regarding yield-related traits of cotton plants under both environmental conditions. The values obtained in the scaling tests are presented in Table 3. The analyses revealed that the model was partially adequate for the data regarding all traits. The regression coefficient ' $b$ ' deviated from zero for all parameters but not from unity, which indicated the absence of non-allelic interactions and independent gene distribution for each character among the parents and the independence of gene actions. As suggested by Mather and Jinks, (1982), the unit slope of the regression lines for all characters revealed that all assumptions of the additive dominance model were met.

Genetics and Molecular Research 15 (4): gmr.15048626 
Table 1. Mean squares of various fiber property traits in an $8 \times 8$ diallel cross under a normal water regime.

\begin{tabular}{l|c|c|c|c}
\hline Source & d.f. & Fiber length & Fiber strength & Fiber fineness \\
\hline Replicates & 2 & 0.631 & 0.2463 & 0.144 \\
\hline Genotypes & 63 & $3.96^{* *}$ & $3.67^{* *}$ & $3.282^{* *}$ \\
\hline Error & 126 & 0.903 & 0.733 & 0.149 \\
\hline
\end{tabular}

$* *$ Highly significant. d.f. $=$ degrees of freedom.

Table 2. Mean squares of various fiber property traits in an $8 \times 8$ diallel cross under a water stress regime.

\begin{tabular}{l|c|c|c|c}
\hline Source & d.f. & Fiber length & Fiber strength & Fiber fineness \\
\hline Replications & 2 & 1.067 & 0.558 & 0.011 \\
\hline Genotypes & 63 & $3.78^{* *}$ & $2.272^{* *}$ & $2.205^{* *}$ \\
\hline Error & 126 & 0.982 & 1.488 & 0.103 \\
\hline
\end{tabular}

**Highly significant. d.f. $=$ degrees of freedom.

Table 3. Scaling tests to determine the adequacy of the additive-dominance model for data regarding different fiber property traits under normal and water stress regimes.

\begin{tabular}{|c|c|c|c|c|}
\hline \multirow[t]{2}{*}{ Traits } & \multirow[t]{2}{*}{ Joint regression analysis } & \multicolumn{2}{|c|}{ Mean squares } & \multirow[t]{2}{*}{ Remarks } \\
\hline & & $\mathrm{Wr}+\mathrm{Vr}$ & $\mathrm{Wr}-\mathrm{Vr}$ & \\
\hline \multicolumn{5}{|l|}{ Normal } \\
\hline Fiber strength & $0.966 \pm 0.164$ & $0.162^{\mathrm{NS}}$ & $0.032^{\mathrm{NS}}$ & Partially adequate \\
\hline Fiber fineness & $1.109 \pm 0.143$ & $0.030^{\mathrm{NS}}$ & $0.002^{\mathrm{NS}}$ & Partially adequate \\
\hline Fiber length & $0.993 \pm 0.227$ & $1.855^{\mathrm{NS}}$ & $0.235^{\mathrm{NS}}$ & Partially adequate \\
\hline \multicolumn{5}{|l|}{ Water stress } \\
\hline Fiber strength & $0.0897 \pm 0.174$ & $0.700^{\mathrm{NS}}$ & $0.172^{\mathrm{NS}}$ & Partially adequate \\
\hline Fiber fineness & $0.907 \pm 0.012$ & $0.009^{\mathrm{NS}}$ & $0.001^{\mathrm{NS}}$ & Partially adequate \\
\hline Fiber length & $0.996 \pm 0.228$ & $1.565^{\mathrm{NS}}$ & $0.360^{\mathrm{NS}}$ & Partially adequate \\
\hline
\end{tabular}

$\mathrm{Wr}+\mathrm{Vr}=$ difference between the arrays. $\mathrm{Wr}-\mathrm{Vr}=$ difference within the arrays.

\section{Fiber strength}

Significant estimates of $\mathrm{D}$ (additive variance), $\mathrm{H}_{1}$ (component of variation due to dominant effects of genes), and $\mathrm{H}_{2}$ (component of variation due to dominant effects of genes correlated with gene distribution) (Table 4) revealed the importance of additive and nonadditive (dominance) effects in the genetic control of fiber strength under normal and drought conditions. The magnitude of $\mathrm{H}_{1}$ and $\mathrm{H}_{2}$ seemed to be almost equal under both treatment regimes, which indicated approximately equal gene frequencies at all loci. The estimates of $\mathrm{H}_{2} / 4 \mathrm{H}_{1}(0.24$ and 0.23$)$ were also almost equal to 0.25 , which implied symmetrical distribution of positive and negative alleles. Positive and significant $\mathrm{F}$ values under a normal water regime indicated that dominant alleles occur more frequently than recessive alleles, whereas, under drought, $\mathrm{F}$ is not significant. Hence, the parents carried approximately the same number of dominant and recessive genes, with the negative sign implying a trend towards recessiveness. This was further supported by the estimates of $\sqrt{4} \mathrm{DH}_{1}+\mathrm{F} / \sqrt{ } 4 \mathrm{DH}_{1}-\mathrm{F}$, which are greater than 1 under normal conditions but lower under drought conditions. Partial dominance was evident from the estimates of $\left(\mathrm{H}_{1} / \mathrm{D}\right)^{0.5}$, which were 0.85 under normal conditions and 0.92 under water stress. The value of 0.92 obtained under drought is almost equal to 1.0, showing near-

Genetics and Molecular Research 15 (4): gmr.15048626 
to-complete dominance. Positive and significant values of $\mathrm{h}^{2}$ indicated that dominance was established with a tendency towards increased fiber strength. The environment had a significant effect on the expression of this trait. The estimates of $\mathrm{h}^{2}{ }_{\mathrm{Ns}}$ were moderate $(0.54$ and 0.42$)$ under both conditions.

\section{Table 4. Components of genetic variation under normal and water stress regimes.}

\begin{tabular}{l|c|c|c|c|c|c|c|c|c|c}
\hline Traits & $\mathrm{D}$ & $\mathrm{H} 1$ & $\mathrm{H} 2$ & $\mathrm{~F}$ & $\mathrm{~h}^{2}$ & $\mathrm{E}$ & $(\mathrm{H} / \mathrm{D})^{0.5}$ & $\left(\sqrt{ } 4 \mathrm{DH}_{1}+\mathrm{F} / \sqrt{ } 4 \mathrm{DH} \mathrm{H}_{1}-\mathrm{F}\right)$ & $\left(\mathrm{H}_{2} / 4 \mathrm{H}_{1}\right)$ & $\mathrm{h}^{2} \mathrm{Ns}$ \\
\hline Normal & & & & & & & & & \\
\hline FS & $0.23 \pm 0.04^{*}$ & $0.17 \pm 0.06^{*}$ & $0.16 \pm 0.08^{*}$ & $0.21 \pm 0.10^{*}$ & $0.11 \pm 0.05^{*}$ & $0.25 \pm 0.01^{*}$ & 0.85 & 3.33 & 0.24 & 0.54 \\
\hline FF & $0.14 \pm 0.04^{*}$ & $0.17 \pm 0.03^{*}$ & $0.10 \pm 0.02^{*}$ & $0.18 \pm 0.03^{*}$ & $0.04 \pm 0.02^{*}$ & $0.05 \pm 0.004^{*}$ & 1.12 & 4.10 & 0.15 & 0.09 \\
\hline FL & $1.79 \pm 0.16^{*}$ & $1.13 \pm 0.368^{*}$ & $0.87 \pm 0.32^{*}$ & $1.02 \pm 0.38^{*}$ & $-0.09 \pm 0.21^{\mathrm{NS}}$ & $-0.31 \pm 0.21^{\mathrm{NS}}$ & 0.79 & 2.12 & 0.19 & 0.49 \\
\hline Water stress & & & & & & & & & & \\
\hline FS & $0.63 \pm 0.07^{*}$ & $0.54 \pm 0.18^{*}$ & $0.51 \pm 0.15^{*}$ & $-0.07 \pm 0.18^{\mathrm{NS}}$ & $0.21 \pm 0.10^{*}$ & $0.51 \pm 0.02^{*}$ & 0.92 & 0.88 & 0.23 & 0.42 \\
\hline FF & $0.079 \pm 0.005^{*}$ & $0.04 \pm 0.01^{*}$ & $0.03 \pm 0.01^{*}$ & $0.06 \pm 0.02^{*}$ & $-0.05 \pm 0.03^{\mathrm{NS}}$ & $0.03 \pm 0.001^{*}$ & 0.74 & 3.40 & 0.19 & 0.54 \\
\hline FL & $1.77 \pm 0.15^{*}$ & $1.05 \pm 0.36^{*}$ & $0.81 \pm 0.31^{*}$ & $0.97 \pm 0.37^{*}$ & $-0.10 \pm 0.09^{\mathrm{NS}}$ & $-0.34 \pm 0.19^{\mathrm{NS}}$ & 0.77 & 2.10 & 0.19 & 0.48 \\
\hline
\end{tabular}

$\mathrm{D}=$ additive variance; $\mathrm{H}_{1}=$ component of variation due to the dominant effects of genes; $\mathrm{H}_{2}=$ component of variation due to the dominant effects of genes correlated with gene distribution; $\mathrm{F}=$ relative frequency of dominant and recessive alleles in the parents; $\mathrm{h}^{2}=$ overall dominance effects of heterozygous loci; $\mathrm{E}=$ environmental variance; $\left(\mathrm{H}_{1} / \mathrm{D}\right)^{0.5}=$ mean degree of dominance; $\sqrt{4} \mathrm{DH}_{1}+\mathrm{F} / \sqrt{ } 4 \mathrm{DH}_{1}-\mathrm{F}=$ proportion of dominant and recessive genes in the parents; $\mathrm{H}_{2} / 4 \mathrm{H}_{1}$ = proportion of genes with positive and negative effects in the parents; $\mathrm{h}^{2}{ }_{\mathrm{Ns}}=$ narrow-sense heritability.

The $\mathrm{Vr} / \mathrm{Wr}$ graphs (Figures 1 and 2) showed that the regression lines with unit slopes passed through the $\mathrm{Wr}$ axes above the origin, thus indicating additive effects on the control of fiber strength inheritance under both water regimes. The highest number of dominant genes was observed for CIM-482, which was closest to the origin, with the variety FH-900 being the farthest from the origin and possessing the highest number of recessive genes under normal conditions. Under drought conditions, the dominant genes were carried by VH-142 and the reverse was true for CIM-446.

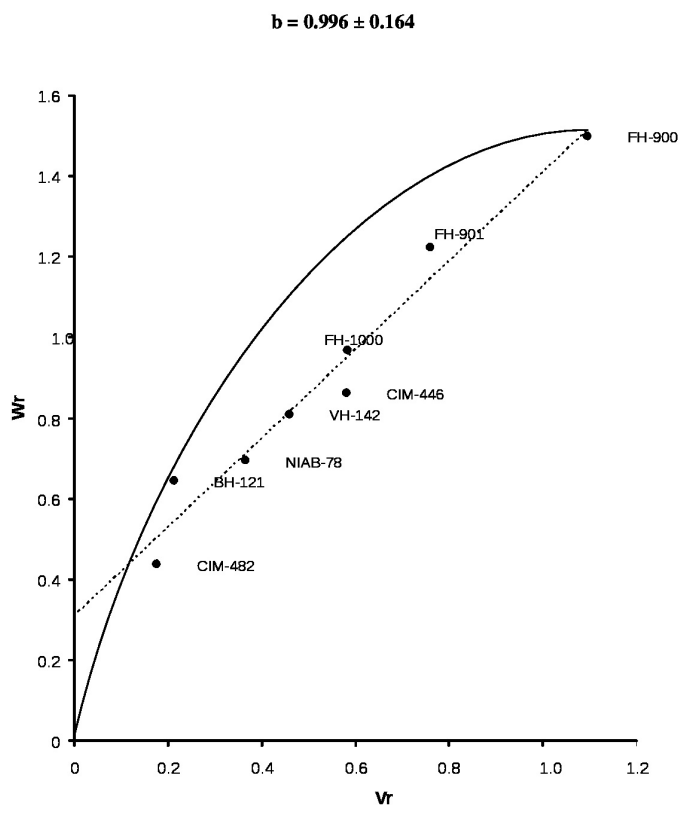

Figure 1. $\mathrm{Vr} / \mathrm{Wr}$ graph for fiber strength under normal water regime.

Genetics and Molecular Research 15 (4): gmr.15048626 


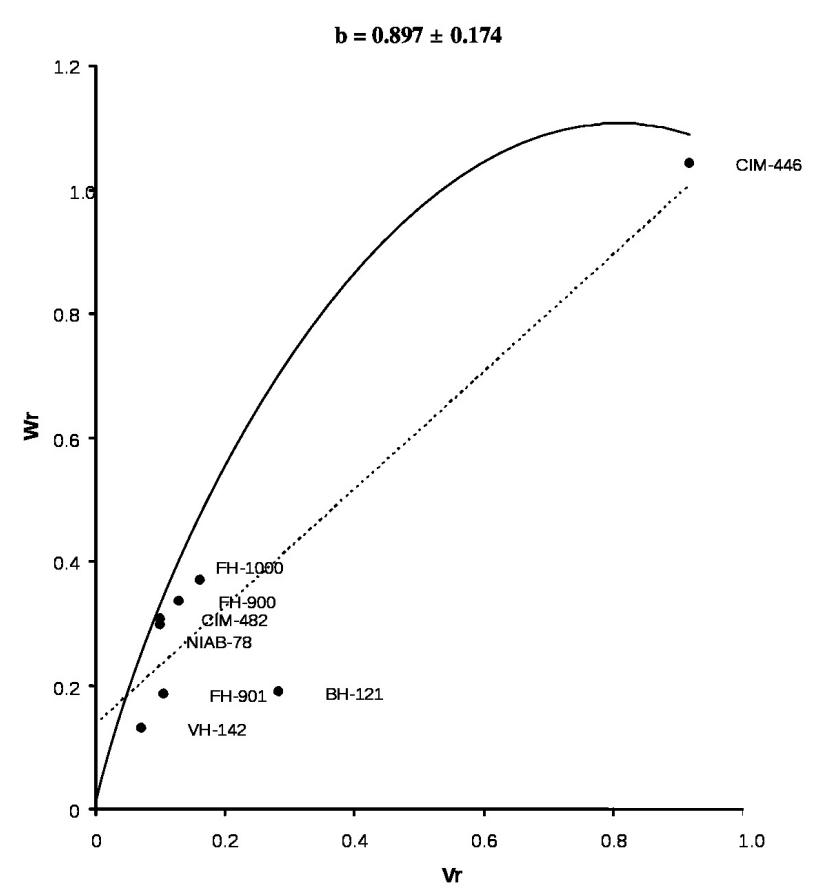

Figure 2. $\mathrm{Vr} / \mathrm{Wr}$ graph for fiber strength under water stress regime.

Tables 5 and 6 show that the highest general combining ability (GCA) effects were observed for NIAB-78, which had the maximum array means under both water conditions (26.77 and 26.34). The best effect on specific combining ability (SCA) was observed with CIM-446. The cross NIAB-78 x CIM-446 had the highest mean values within arrays under normal and water stress conditions (27.17 and 27.02).

Table 5. Mean $8 \times 8$ diallel table for fiber strength under a normal water regime.

\begin{tabular}{l|c|c|c|c|c|c|c|c}
\hline & NIAB-78 & CIM-482 & BH-121 & VH-142 & FH-900 & CIM-446 & FH-1000 & FH-901 \\
\hline NIAB-78 & 27.13 & 26.97 & 26.65 & 26.82 & 26.38 & 27.17 & 26.20 & 26.85 \\
\hline CIM-482 & 26.97 & 26.83 & 25.98 & 26.75 & 26.75 & 26.62 & 25.80 & 26.37 \\
\hline BH-121 & 26.65 & 25.98 & 25.83 & 26.48 & 26.48 & 26.05 & 25.45 & 25.55 \\
\hline VH-142 & 26.82 & 26.75 & 26.48 & 26.67 & 26.30 & 26.75 & 26.33 & 26.40 \\
\hline FH-900 & 26.38 & 26.75 & 26.48 & 26.30 & 25.37 & 26.33 & 25.63 & 25.27 \\
\hline CIM-446 & 27.17 & 26.62 & 26.05 & 26.75 & 26.33 & 27.90 & 25.98 & 25.92 \\
\hline FH-1000 & 26.20 & 25.80 & 25.48 & 26.33 & 25.63 & 25.98 & 25.27 & 25.30 \\
\hline FH-901 & 26.85 & 26.37 & 25.55 & 26.40 & 25.27 & 25.92 & 25.30 & 25.30 \\
\hline Mean & 26.77 & 26.51 & 26.06 & 26.56 & 26.06 & 26.59 & 25.75 & 25.87 \\
\hline
\end{tabular}

Both additive and non-additive effects were noted in the inheritance of fiber fineness under both conditions, as the estimates of $\mathrm{D}, \mathrm{H}_{1}$, and $\mathrm{H}_{2}$ were significant (Table 4). The magnitude of $\mathrm{H}_{1}$ was higher than that of $\mathrm{D}$, as well as that of $\mathrm{H}_{2}$, therefore indicating unequal allele frequencies at all loci with an excess of dominant alleles. This was further supported by the positive and significant $\mathrm{F}$ values and the estimates of $\sqrt{4} \mathrm{DH}_{1}+\mathrm{F} / \sqrt{4} \mathrm{DH}_{1}-\mathrm{F}$, which were more than 1.0 under both conditions. Asymmetrical distribution of positive and negative alleles was also supported by the values of $\mathrm{H}_{2} / 4 \mathrm{H}_{1}$, which were less than 0.25 under both 
conditions. However, dominance was positive under normal conditions but bidirectional under water stress. The value of $\left(\mathrm{H}_{1} / \mathrm{D}\right)^{0.5}$ under the normal water regime was more than 1.0 indicating overdominance, whereas it indicated partial dominance $(0.74)$ under water stress. The environment effect was also evident. The $\mathrm{h}^{2}{ }_{\mathrm{Ns}}$ was very low under normal conditions whereas it was moderate under drought conditions.

Table 6. Mean 8 x 8 diallel table for fiber strength under a water stress regime.

\begin{tabular}{l|c|c|c|c|c|c|c|c}
\hline & NIAB-78 & CIM-482 & BH-121 & VH-142 & FH-900 & CIM-446 & FH-1000 & FH-901 \\
\hline NIAB-78 & 26.75 & 26.39 & 26.37 & 26.38 & 26.01 & 27.02 & 25.46 & 26.31 \\
\hline CIM-482 & 26.39 & 26.46 & 25.99 & 26.38 & 26.38 & 26.67 & 25.43 & 26.16 \\
\hline BH-121 & 26.37 & 25.99 & 25.46 & 26.36 & 26.13 & 26.15 & 25.11 & 25.63 \\
\hline VH-142 & 26.38 & 26.38 & 26.36 & 26.30 & 25.93 & 26.05 & 25.96 & 26.03 \\
\hline FH-900 & 26.01 & 26.38 & 26.13 & 25.93 & 25.00 & 25.27 & 24.69 & 24.61 \\
\hline CIM-446 & 27.02 & 26.67 & 26.15 & 26.05 & 25.27 & 27.88 & 25.61 & 25.55 \\
\hline FH-1000 & 25.46 & 25.43 & 25.11 & 25.96 & 24.69 & 25.61 & 24.90 & 24.89 \\
\hline FH-901 & 26.31 & 26.16 & 25.63 & 26.03 & 24.61 & 25.55 & 24.89 & 24.93 \\
\hline Mean & 26.34 & 26.23 & 25.90 & 26.17 & 25.50 & 26.28 & 25.26 & 25.51 \\
\hline
\end{tabular}

The $\mathrm{Vr} / \mathrm{Wr}$ graph (Figure 3) showing the normal water regime revealed an overdominance type of gene activity controlling the genetic mechanism of fiber fineness as the regression line intercepted the $\mathrm{Wr}$ axis below the origin. The parent CIM-482 carries the highest number of dominant genes, whereas CIM-446 recessive being the closest and farthest from the origin, respectively. Similarly, Figure 4 shows that the highest number of dominant genes under the drought condition was carried by VH-142, and the recessive genes were carried by CIM-446. In addition, the genes were additive with partial dominance as the regression line passed through the $\mathrm{Wr}$ axis above the origin. The mean values presented in Table 7 indicated that $\mathrm{BH}-121$ and $\mathrm{FH}-1000$ gave high array means, thus proving to be good general combiner in terms of the high figures obtained. However, fiber fineness is measured in micronaires; this unit is defined as fiber weight in micrograms per inch; therefore, the lower the weight the finer the fiber. Thus, lower micronaire values would be preferred by breeders. The NIAB-78 variety, which showed the lowest mean (4.77), will therefore be a good choice, and its combination with CIM-446, which has an array value of 4.45, would be appropriate.

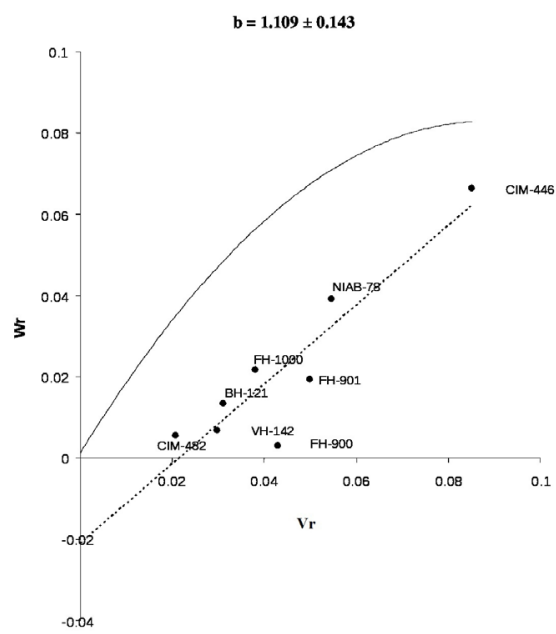

Figure 3. Wr/Vr graph for fiber fineness under normal water regime.

Genetics and Molecular Research 15 (4): gmr.15048626 


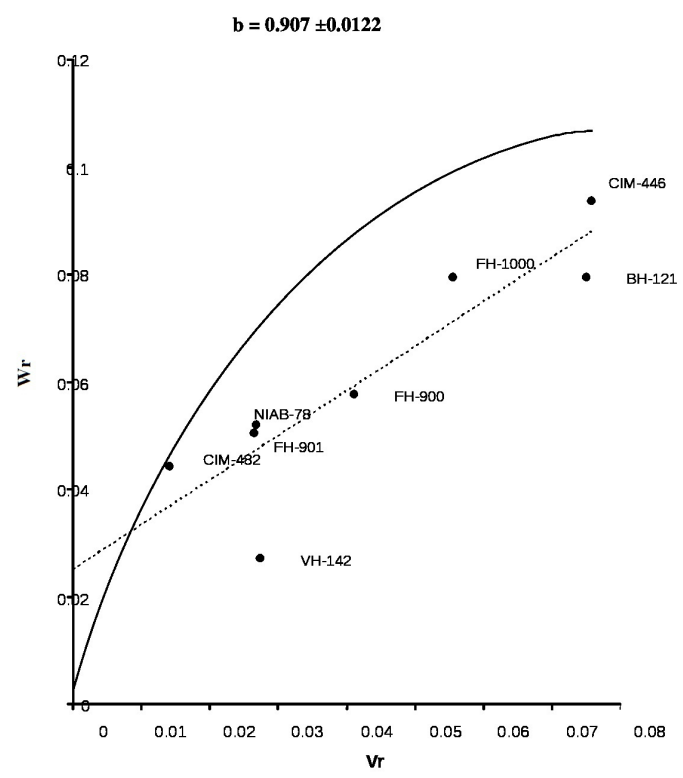

Figure 4. $\mathrm{Vr} / \mathrm{Wr}$ graph for fiber fineness under water stress regime.

Table 7. Mean $8 \times 8$ diallel table for fiber fineness under a normal water regime.
\begin{tabular}{l|c|c|c|c|c|c|c|c}
\hline & NIAB-78 & CIM-482 & BH-121 & VH-142 & FH-900 & CIM-446 & FH-1000 & FH-901 \\
\hline NIAB-78 & 4.63 & 4.65 & 4.90 & 4.78 & 4.97 & 4.45 & 4.78 & 4.98 \\
\hline CIM-482 & 4.65 & 5.17 & 4.87 & 4.87 & 4.82 & 5.28 & 4.77 & 4.97 \\
\hline BH-121 & 4.90 & 4.87 & 6.03 & 4.92 & 4.83 & 4.80 & 5.17 & 4.83 \\
\hline VH-142 & 4.78 & 4.87 & 4.92 & 4.93 & 5.32 & 5.10 & 4.83 & 5.02 \\
\hline FH-900 & 4.97 & 4.82 & 4.83 & 5.32 & 4.93 & 4.97 & 5.13 & 4.63 \\
\hline CIM-446 & 4.45 & 5.28 & 4.80 & 5.10 & 4.97 & 4.93 & 5.28 & 4.70 \\
\hline FH-1000 & 4.78 & 4.77 & 5.17 & 4.83 & 5.13 & 5.28 & 5.10 & 5.10 \\
\hline FH-901 & 4.98 & 4.97 & 4.83 & 5.02 & 4.63 & 4.70 & 5.10 & 4.73 \\
\hline Mean & 4.77 & 4.92 & 5.04 & 4.97 & 4.95 & 4.94 & 5.02 & 4.87 \\
\hline
\end{tabular}

Similarly, under drought conditions (Table 8), CIM-446 had the lowest mean (4.68) and would be considered a good combiner, and its cross with FH-901, which had the lowest mean within the array, would be a good combination.

Table 8. Mean $8 \times 8$ diallel table for fiber fineness under a water stress regime.

\begin{tabular}{l|c|c|c|c|c|c|c|c}
\hline & NIAB-78 & CIM-482 & BH-121 & VH-142 & FH-900 & CIM-446 & FH-1000 & FH-901 \\
\hline NIAB-78 & 4.67 & 4.70 & 4.82 & 4.83 & 4.78 & 4.55 & 4.72 & 4.62 \\
\hline CIM-482 & 4.77 & 5.00 & 5.17 & 5.08 & 4.97 & 4.98 & 4.98 & 4.85 \\
\hline BH-121 & 4.82 & 5.17 & 5.23 & 5.25 & 5.02 & 4.97 & 4.92 & 4.73 \\
\hline VH-142 & 4.83 & 5.08 & 5.25 & 5.17 & 5.07 & 4.90 & 5.08 & 4.77 \\
\hline FH-900 & 4.78 & 4.97 & 5.02 & 5.07 & 4.90 & 4.62 & 4.95 & 4.92 \\
\hline CIM-446 & 4.55 & 4.98 & 4.97 & 4.90 & 4.62 & 4.17 & 4.73 & 4.53 \\
\hline FH-1000 & 4.72 & 4.98 & 4.92 & 5.08 & 4.95 & 4.73 & 4.90 & 4.88 \\
\hline FH-901 & 4.62 & 4.85 & 4.73 & 4.77 & 4.92 & 4.53 & 4.88 & 4.67 \\
\hline Mean & 4.72 & 4.97 & 5.01 & 5.02 & 4.90 & 4.68 & 4.90 & 4.75 \\
\hline
\end{tabular}

Genetics and Molecular Research 15 (4): gmr.15048626 


\section{Fiber length}

Significant estimates of $\mathrm{D}$ and $\mathrm{H}\left(\mathrm{H}_{1}, \mathrm{H}_{2}\right)$ for fiber length indicated the importance of additive and non-additive effects under both environments. A higher magnitude of $\mathrm{H}_{1}$ than that of $\mathrm{H}_{2}$ and a significant positive value of $\mathrm{F}$ revealed unequal allele frequency with more frequent dominant alleles. It was further evident that $\mathrm{H}_{2} / 4 \mathrm{H}_{1}$ was less than 0.25 and $\sqrt{ } 4 \mathrm{DH}_{1}+\mathrm{F} / \sqrt{ } 4 \mathrm{DH}_{1}-\mathrm{F}$ was more than 1.0, indicating that there was an excess of dominant genes in the parents.

Nonsignificant $\mathrm{h}^{2}$ revealed that the overall dominance effects of the heterozygous loci were bidirectional. The effect of the environment on the expression of this character seemed to be nonsignificant. The estimates of $\mathrm{h}^{2}{ }_{\mathrm{Ns}}$ were moderate, with a magnitude of 0.49 and 0.48 under normal and water stress conditions, respectively.

From the graphs shown in Figures 5 and 6, additive types of gene activity with partial dominance were indicated to control the inheritance of fiber length as the regression lines with unit slopes passed through the $\mathrm{Wr}$ axes above the origins under both water regimes. However, a change in gene distribution among the parents was observed under the two conditions. Under normal conditions, the highest number of dominant genes was possessed by CIM-482 and the recessive genes were carried by CIM-446, which were close and distance from the origin, respectively. However, under water stress, the dominant genes were possessed by VH-142 and the reverse was true for $\mathrm{FH}-1000$.

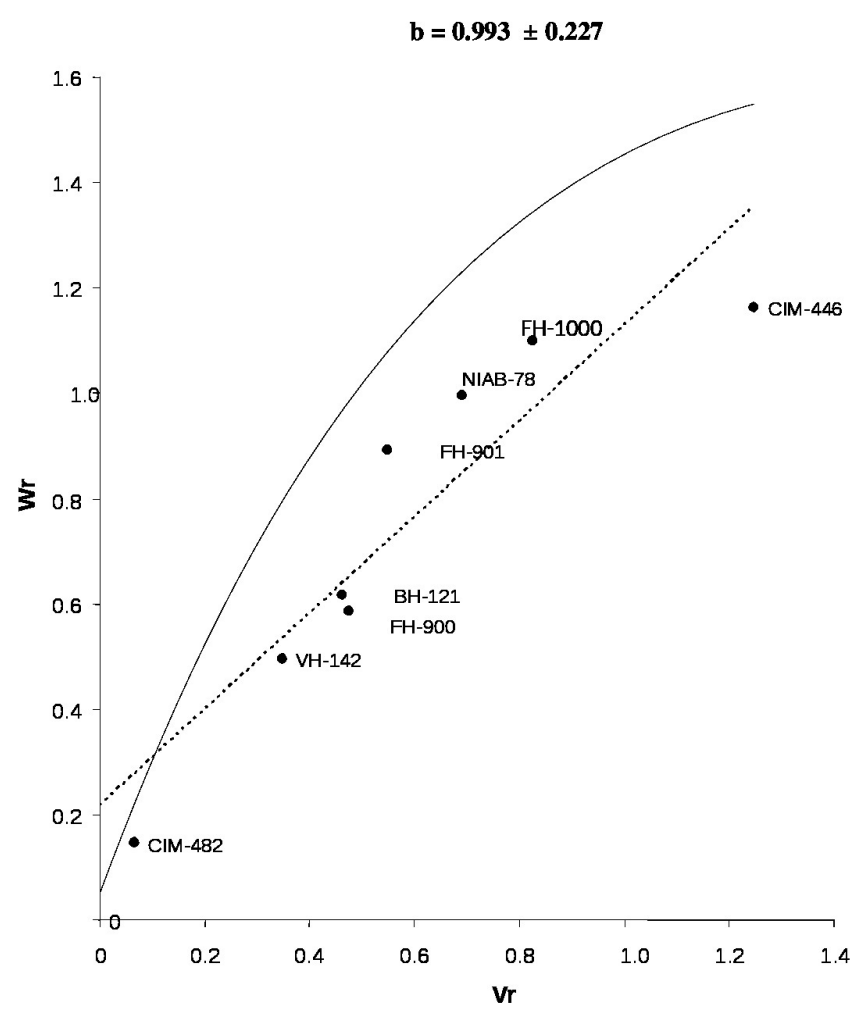

Figure 5. Vr/Wr graph for fiber length under normal water regime.

Genetics and Molecular Research 15 (4): gmr.15048626 


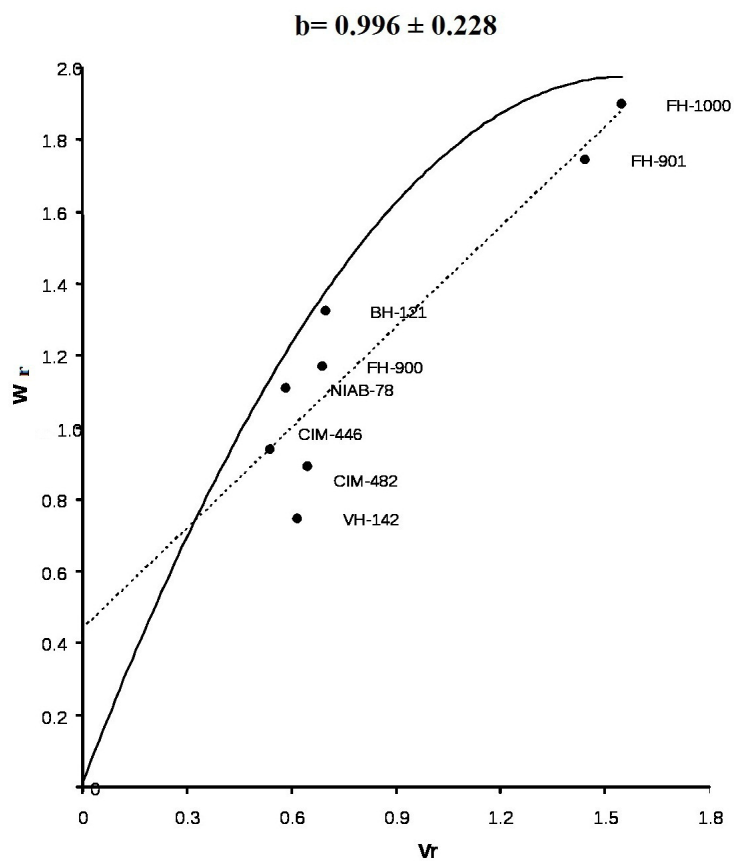

Figure 6. $\mathrm{Vr} / \mathrm{Wr}$ graph for fiber length under water stress regime.

The parent CIM-482 proved to be the best general combiner as it obtained the highest array means (28.05 and 27.34) under both environments, whereas it performed well in combination with NIAB-78 in the arrays (Tables 9 and 10).

\section{Table 9. Mean 8 x 8 diallel table for fiber length under a normal water regime.}

\begin{tabular}{l|c|c|c|c|c|c|c|c}
\hline & NIAB-78 & CIM-482 & BH-121 & VH-142 & FH-900 & CIM-446 & FH-1000 & FH-901 \\
\hline NIAB-78 & 28.50 & 28.62 & 29.33 & 26.40 & 28.08 & 27.30 & 27.33 & 27.92 \\
\hline CIM-482 & 28.62 & 28.77 & 28.38 & 27.02 & 27.58 & 27.85 & 28.40 & 27.78 \\
\hline BH-121 & 29.33 & 28.38 & 28.63 & 27.22 & 26.12 & 26.80 & 26.17 & 26.72 \\
\hline VH-142 & 26.40 & 27.02 & 27.22 & 27.90 & 26.43 & 26.93 & 27.87 & 26.93 \\
\hline FH-900 & 28.08 & 27.58 & 26.12. & 26.43 & 26.40 & 26.33 & 26.63 & 26.77 \\
\hline CIM-446 & 27.30 & 27.85 & 26.80 & 26.93 & 26.33 & 25.80 & 26.28 & 26.73 \\
\hline FH-1000 & 27.33 & 28.40 & 26.17 & 27.87 & 26.63 & 26.28 & 26.00 & 26.70 \\
\hline FH-901 & 27.92 & 27.78 & 26.72 & 26.93 & 26.77 & 26.73 & 26.70 & 25.97 \\
\hline Mean & 27.94 & 28.05 & 27.42 & 27.09 & 26.67 & 26.75 & 26.92 & 26.94 \\
\hline
\end{tabular}

\section{Table 10. Mean 8 x 8 diallel table for fiber length under a water stress regime.}

\begin{tabular}{l|c|c|c|c|c|c|c|c}
\hline & NIAB-78 & CIM-482 & BH-121 & VH-142 & FH-900 & CIM-446 & FH-1000 & FH-901 \\
\hline NIAB-78 & 27.78 & 27.95 & 28.61 & 25.63 & 27.36 & $26.5 / 8$ & 26.61 & 27.20 \\
\hline CIM-482 & 27.95 & 28.05 & 27.66 & 26.30 & 26.86 & 27.13 & 27.88 & 27.06 \\
\hline BH-121 & 28.61 & 27.66 & 27.91 & 26.50 & 25.40 & 26.08 & 25.45 & 26.00 \\
\hline VH-142 & 25.68 & 26.30 & 26.50 & 27.18 & 25.71 & 26.21 & 27.15 & 26.21 \\
\hline FH-900 & 27.36 & 26.86 & 25.40 & 25.71 & 26.68 & 25.61 & 25.91 & 26.05 \\
\hline CIM-446 & 26.58 & 27.13 & 26.08 & 26.21 & 25.61 & 25.08 & 25.56 & 26.01 \\
\hline FH-1000 & 26.61 & 27.68 & 25.45 & 27.15 & 25.91 & 25.56 & 25.28 & 25.98 \\
\hline FH-901 & 27.20 & 27.06 & 26.00 & 26.21 & 26.05 & 26.01 & 25.98 & 25.25 \\
\hline Mean & 27.22 & 27.34 & 26.70 & 26.37 & 25.95 & 26.03 & 26.20 & 26.22 \\
\hline
\end{tabular}

Genetics and Molecular Research 15 (4): gmr.15048626 


\section{DISCUSSION}

The availability of variation in plant characteristics may be advantageous to breeders if it is genetically controlled. The diallel cross method used in the present study provided information on the pattern of inheritance for variation in fiber properties. The simple additivedominance model was found to be partially adequate in all cases under both water regimes, for example, in barley (Johnson and Aksel, 1964), Sorghum (Azhar and McNeilly, 1988), and cotton (Murtaza et al., 2002; Khan et al., 2003; Murtaza et al., 2005). These authors also studied the inheritance pattern of different characters and, therefore, the data under study indicating complete as well as partial adequacy for the model.

Higher magnitudes of additive variance revealed that the effects of additive genes were more pronounced. This was further supported by the $\mathrm{Vr} / \mathrm{Wr}$ graphs for traits where gene activity was noted to be additive with partial dominance. Higher estimates of narrowsense heritability for the traits also reflect the high magnitudes of additive variance. Additive variance without epistatic effects and high heritability seems to be encouraging for researchers aiming to improve drought tolerance in cotton plants. Similar results were reported by Malik et al. (2013) in cotton, by Akram et al. (2007) in rice, and by El-Rawy and Hassan (2014) in bread wheat.

In the present study, fiber properties such as strength, length, and fineness were found to be controlled by both additive and non-additive effects. However, the influence of additive effects was more prominent than that of non-additive effects, which was evident from the graphic representations of the characters, where they were all shown to be controlled by additive gene actions with partial dominance.

The genetic components of variation in fiber quality traits indicated the presence of additive as well as dominant effects in their inheritance under both water regimes. Additive gene action was also found to be involved in the inheritance of fiber strength and length under both conditions. However, in case of fiber fineness, overdominance was observed under normal conditions and additive effects with partial dominance were observed under drought conditions. Those results are similar to the observations of Nadarajan and Rangasamy (1992), May and Green (1994), and Green and Culp (1990) who reported that fiber length, strength, and fineness were controlled by both additive and non-additive gene effects. Jana (1975) reported that gene actions change with experimental conditions, and that genetic mechanisms controlling most of these characters are complex. Estimates of heritability (Ns) were moderate in all cases; however, they were very low for fiber fineness under normal conditions where the magnitude of additive variance was lower than that of dominance variance.

Fiber quality traits are very important in any cotton improvement program because of their importance in the textile industry. In the present study, additive gene activities, without complication by epistasis and with considerable narrow-sense heritability, provide the possibility for such improvement through simple selection procedures. However, one must be careful while selecting for better fiber fineness. Fineness is measured in micronaire, which is defined as the weight of fiber in micrograms per inch; therefore, the lower the weight, the finer the fiber. Therefore, lower micronaire values will be the choice of the breeders.

In conclusion, both additive and non-additive gene effects were involved in the inheritance mechanisms of almost all of the investigated traits. A higher overall magnitude of additive variance revealed that the effect of additive genes was greater. This was further supported by the $\mathrm{Vr} / \mathrm{Wr}$ graphs for the traits where the gene activity was noted to be additive

Genetics and Molecular Research 15 (4): gmr.15048626 
with partial dominance and with no involvement of epistatic effects. Generally, estimates of narrow-sense heritability were high. Taken together, these data reveal the promising potential of germplasm for the possible improvement of water stress tolerance in cotton genotypes through conventional selection procedures in segregating generations.

\section{Conflicts of interest}

The authors declare no conflict of interest.

\section{ACKNOWLEDGMENTS}

Special thanks to Dr. Iftikhar Ahmad Khan (Tamgha-e-Imtiaz and Azaz-e-Fazelat) for providing guidance on every step and helping to carry out this research.

\section{REFERENCES}

Akram M, Ajmal SU and Munir M (2007). Inheritance of traits related to seedling vigor and grain yield in rice (Oryza sativa L.). Pak. J. Bot. 391: 37.

Azhar FM and McNeilly T (1988). The genetic basis of variation for salt tolerance in Sorghum bicolor (L) Moench seedlings. Plant Breed. 101: 114-121. http://dx.doi.org/10.1111/j.1439-0523.1988.tb00275.x

Ball RA, Derrick MO and Mauromoustakos A (1994). Growth dynamics of cotton plant during water-stress stress. Agron. J. 86: 788-795. http://dx.doi.org/10.2134/agronj1994.00021962008600050008x

Basal H, Smith CW, Thaxton PM and Hemphill JK (2005). Seedling drought tolerance in upland cotton. Crop Sci. 45: 766-771. http://dx.doi.org/10.2135/cropsci2005.0766

Cook CG (1985). Identifying root traits among MAR and non-MAR cotton, Gossypium hirsutum L. cultivars that relate to performance under limited moisture conditions. Master thesis, Texas A \& M University, College Station.

El-Rawy MA and Hassan MI (2014). A Diallel Analysis of Drought Tolerance Indices at Seedling Stage in Bread Wheat (Triticum aestivum L.). Kor. Soc. Breed. Sci. 2: 276-288.

Gerik TJ, Faver KL, Thanton PM and El-Zik KM (1996). Late season water stress in cotton. Crop Sci. 36: 914-921. http:// dx.doi.org/10.2135/cropsci1996.0011183X003600040017x

Green CC and Culp TW (1990). Simultaneous improvements of yield, fibre quality, and yarn strength in upland cotton. Crop Sci. 30: 66-69. http://dx.doi.org/10.2135/cropsci1990.0011183X003000010015x

Hayman BI (1954a). The theory and analysis of diallel crosses. Genetics 30: 789-809.

Hayman BI (1954b). The analysis of variance of diallel tables. Biometrics 10: 235-244. http://dx.doi.org/10.2307/3001877

Jana S (1975). Genetic analysis by means of diallel graph. Heredity 35: 1-19. http://dx.doi.org/10.1038/hdy.1975.63

Jinks JL (1954). The analysis of continuous variation in a diallel cross of Nicotiana rustica. Genetics 39: 767-788.

Johnson LPV and Aksel R (1964). The inheritance of malting quality and agronomic characters in a diallel cross of barley. Can. J. Genet. Cytol. 6: 178-200. http://dx.doi.org/10.1139/g64-024

Khan MA, Soomro ZA and Leghari N (2003). Diallel analysis for yield and yield contributing characters in (Gossypium hirsutum L.). Pak. J. Appl. Sci 3: 129-132. http://dx.doi.org/10.3923/jas.2003.129.132

Kohel RJ (1974). Influence of certain morphological character on yield. Cotton Grow. Rev. 51: 281-292.

Leidi EO, Lopez M, Gorham J and Gutierrez JC (1999). Variation in carbon isotope discrimination and other traits to drought tolerance in upland cotton cultivars under dryland conditions. Field Crops Res. 61: 109-123. http://dx.doi. org $/ 10.1016 / \mathrm{S} 0378-4290(98) 00151-8$

Malik W, Iqbal MZ, Khan AA, Noor E, et al. (2013). Genetic basis of variation for seedling traits in Gossypium hirsutum L. Afr. J. Biotechnol. 10: 1099-1105.

Mather K and Jinks JL (1982). Introduction to Biometrical Genetics. Chapman \& Hill Ltd., London.

May OL and Green CC (1994). Genetic variation for Fibre properties in elite Pee Dee cotton populations. Crop Sci. 34: 684-690. http://dx.doi.org/10.2135/cropsci1994.0011183X003400030016x

McMichael BL and Quisenberry JE (1991). Genetic variation for root-shoot relationship among cotton germplasm. Environ. Exp. Bot. 31: 461-470. http://dx.doi.org/10.1016/0098-8472(91)90045-P

Munro JM (1987). Cotton. 2nd edn. Longman Scientific and Technical, Essex.

Genetics and Molecular Research 15 (4): gmr.15048626 
Murtaza N, Khan AA and Qayyum A (2002). Estimation of genetic parameters and gene action for yield of seed cotton and lint percentage in Gossypium hirsutum L. J. Res. Sci 13: 151-159.

Murtaza N, Ali GM and Rahman H (2005). Inheritance of Fibre quality characters in upland cotton genotypes having nonpreference traits for insect pests. J. Food Agric. Environ. 3: 180-184.

Nadarajan N and Rangasamy SR (1992). Genetic analysis of certain fibre characters in Gossypium hirsutum L. Indian J. Genet. Plant Breed. 52: 245-251.

Nepomuceno AL, Oosterhuis DM and Stewart JM (1998). Physiological response of cotton leaves and roots to water stress induced by polyethylene glycol. Environ. Exp. Bot. 40: 29-41. http://dx.doi.org/10.1016/S0098-8472(98)00018-5

Pace PF, Cralle HT, El-Halawany SHM, Cothren JT, et al. (1999). Drought-induced changes in shoot and root growth of young cotton plants. J. Cotton Sci. 3: 183-187.

Quisenberry JE, Roark B and McMichael BL (1982). Use of transpiration decline curves to identify drought-tolerant cotton germplasm. Crop Sci. 22: 918-922. http://dx.doi.org/10.2135/cropsci1982.0011183X002200050004x

Rana RM, Khan SH, Ali Z, Khan AI, et al. (2011). Elucidation of thermotolerance diversity in cotton Gossypium hirsutum L. using physio-molecular approaches. Genet. Mol. Res. 10: 1156-1167. http://dx.doi.org/10.4238/vol10-2gmr1180

Riaz M, Farooq J, Sakhawat G, Mahmood A, et al. (2013). Genotypic variability for root/shoot parameters under water stress in some advanced lines of cotton Gossypium hirsutum L. Genet. Mol. Res. 12: 552-561. http://dx.doi. org/10.4238/2013.February.27.4

Steel RGD, Torrie JH and Deekey DA (1997). Principles and procedures statistics: A biometrical approach. 3rd edn. McGraw Hill Book Co., New York.

Sullivan CY (1972). Mechanism of heat and drought resistance in grain sorghum and methods of measurement. In: Sorghum in Seventies (Rao GP and House LR, eds.). Oxford and IBH Publishing Co., New Delhi.

Turner NC (1986). Adaptation to water stress: a changing perspective. Aust. J. Plant Physiol. 13: 175-190. http://dx.doi. org/10.1071/PP9860175

Genetics and Molecular Research 15 (4): gmr.15048626 